\title{
LABOR EDUCATION AT RUTGERS UNIVERSITY, 1931-1981, AND THE ESTABLISHMENT OF IMLR
}

\author{
BYEUGENE MC ELROY
}

Mr. McElroy is currently Library Associate at the

School of Management and Labor Relations.

In 1997, the Institute of Management and Labor Relations (IMLR) will mark its 50th anniversary. It was on June 19, 1947 that New Jersey Governor Alfred Driscoll signed into law, Assembly Bill 250-A. Passed against the backdrop of the great postwar strike wave that engulfed the United States, this legislation formally established the IMLR. Its primary mission was to promote "harmony and co-operation between management and labor, and greater understanding of industrial and labor relations, thereby to enhance the unity and welfare of the people of the state." In order to carry out this assignment, the IMLR was authorized to "establish programs in order to develop new material and techniques to aid in carrying on the educational activities."

\section{Labor Education Before WWII}

Labor education at Rutgers University predated the establishment of the IMLR by many years. Without question, Rutgers was one of the early pioneers in the field, along with such institutions as the Brookwood Labor College, the Bryn Mawr Summer School for Women, Milwaukee Labor College and the educational extension services of the University of California. However, a precise date cannot be fixed owing to changing perspectives of what actually constituted a labor education program.

By broadly defining labor education to mean workers' education, or the entry of non-matriculating students onto the college campus to attend university-level classes, one could point to the year 1891. In that year, the Extension Department (more commonly known as "Night School") was established at Rutgers College. Its mission was twofold: to uplift by giving non-traditional students the benefit of exposure to university-level instruction in academic (liberal arts) courses; and, to generate revenue for Rutgers and the faculty who taught the courses. Ironically, the early extension curriculum offered little in the way of vocational and technical training for workers. Moreover, organized labor's aloofness to the objectives of workers education explain why the early education extension programs developed 
in fits and starts. Clinging to the doctrine of "voluntarism" and economic action through collective bargaining, Samuel Gompers and the AFL remained skeptical of the university's role as a positive agent for the immediate economic and social advancement of workers, particularly in light of business ties to most institutions of higher learning. Finally, the Panic of 1893 dried up the pool of potential "working class" students. ${ }^{2}$

Not until the 1920s did the first true labor extension programs begin to take shape at several American universities. If by "worker education" one means a vocational-oriented education in which a worker's productive or supervisory skills are developed and enhanced, then the establishment of the Workers Educational Bureau (WEB) in 1921 was the first national organization devoted to labor education. Though technically an independent body, the WEB received financial support from the AFL's Committee on Education and was officially endorsed by Gompers, James Maurer (President of the Pennsylvania Federation of Labor) who served as the organization's first president, and Spencer Miller, Jr., who was the first secretary. In 1929 the AFL assumed complete financial and administrative control of the WEB. This move laid the groundwork for organized labor's contact with university personnel involved with extension education programs. Departing from its doctrine of voluntarism (at least in the labor education field), the AFL hoped to play a leading role in shaping the emerging labor education programs on college campuses. ${ }^{3}$

Parallel developments took place within the academic community which accelerated the implementation and expansion of labor education extension programs. In 1923, the National University Extension Association met in St. Louis and adopted a momentous resolution which endorsed cooperation with trade unions in offering educational services for their members. This meeting brought together two leading figures in the worker/ labor education field, Spencer Miller, Jr., and Dr. Norman Miller, who was then attached to the Pennsylvania State College. Both men shared a longterm commitment to worker education and their influence in the field would be felt at Rutgers well into the 1960s. Also, their different perspectives on labor education mirrored the inherent tension between the labor and academic communities over the objectives and direction of the labor extension programs. ${ }^{4}$

The dichotomy between vocational-oriented educators such as Norman Miller, and class-conscious labor education trade unionists like Spencer Miller, Jr., was present from the moment that labor education became demarcated from the general extension educational programs at several universities. Norman Miller, reflecting the interests of the vocationalists, stressed the benefits derived from an educated workforce. Accepting the reality of corporate ties to institutions of higher learning and the anti-union environment pervasive among academic administrators, he advocated the 
implementation of a practical and technical curriculum free of "outside issues." In contrast, Spencer Miller, Jr., envisioned trade union control in shaping the objectives and curriculum of labor extension programs with universities and faculty playing a supporting and subordinate role.

A special committee was appointed in St. Louis to study worker education as a follow-up to the resolution, with Norman Miller named to the panel. In October 1923 the committee released an outline of the proposed study which met with harsh criticism from Norman Miller. He argued that the proposed labor education program (representing the views of Spencer Miller, Jr.), precluded university involvement with curriculum-design. It was not truly a co-operative project within the framework of university extension activity. In an effort to develop a truly co-operative program, Norman Miller initiated his own survey among 67 Pennsylvania industrialists. His survey concluded that they overwhelmingly rejected any educational extension program that permitted trade unions latitude for bias and indoctrination- in essence complete control over the content of the labor education program. Clearly, representatives of industry and business favored university control. Miller noted: "They called my attention to the fact that University Boards of Trustees, at that time, were anti-union. They thought, further, that such a move could cause the loss of philanthropic gifts to any private institute which might become involved." ${ }^{5}$ Union distrust of early university-based labor education programs did have some merit.

Based on this study, Miller conferred in the spring with Penn State president, John M. Thomas. Thomas endorsed Miller's idea of worker education under university auspices. Miller then corresponded with the president of the Pennsylvania State Federation of Labor (AFL) and proposed the establishment of a workers education program at Penn State in 1926. However, events shifted Miller's focus from Pennsylvania to New Jersey following Thomas' decision to assume the presidency of Rutgers in the summer of 1925. Thomas asked Miller to accompany him to Rutgers and develop the proposed University Extension Division in New Brunswick. ${ }^{6}$

Ironically, Miller's move to New Jersey placed him in direct confrontation with Spencer Miller, Jr., who was a resident of the state. Both men staunchly defended their ideological position on workers education: Spencer Miller opting for an independent program with University endorsement, and Norman Miller favoring university control over the direction of labor education. New Jersey labor leaders refused to support any program until the two resolved their differences.

Norman Miller wasted little time in initiating his visions for labor education. The Rutgers Board of Trustees approved the establishment of an Industrial Extension Department on October 10, 1925, with Miller appointed as director. On January 5, 1926, a preliminary conference was held in Miller's office to discuss the educational objectives of industry. It 
was determined that an executive training course for foremen and a more formal educational program for apprentices were among the most pressing needs. Within weeks, five executive training programs were inaugurated. Interest in Norman Miller's program increased to such an extent that Rutgers hosted its first annual industrial conference on September 14-15, 1926. This conference was attended by 167 business leaders and trade union delegates, one of whom was Spencer Miller, Jr. ${ }^{7}$

Inspired by the success of the Bryn Mawr Summer Institute for women factory workers, Norman Miller offered a summer school for "factory girls" at Rutgers in 1927. ${ }^{8}$ Miller endeavored a variation of the Bryn Mawr plan which had focused exclusively on liberal arts courses for women. However, this experiment failed after one year due to the preponderance of women requesting courses in home economics. The next summer, 1928, Miller led an academic delegation to Europe to observe workers education programs in England, Germany, France and Switzerland. After a meeting with Warden Mallan, a British Labour MP, to discuss the workers' education program at Toynbee Hall, Miller wrote:

This led to the germ of an idea, namely that labor in New Jersey could have its own separate program, but under University Extension auspices, by having their men, either from savings or by scholarship, spend a few days or a week on the campus of Rutgers University.... This would combine Spencer Miller's idea of a separate labor cultural program with mine of a joint University Extension program. ${ }^{9}$

Even the Great Depression did not thwart Miller's plans for a bonafide labor institute. In a series of meetings held during the winter of 1929-1930, a compromise was reached whereby the proposed labor institute would be a tripartite undertaking with a joint committee representing Rutgers University, the New Jersey State Federation of Labor (NJSFL-AFL), and the Workers Education Bureau. President Thomas agreed with the proposal but sought official endorsement from the NJSFL-AFL. This was achieved at that organization's convention which convened in Atlantic City on September 15-17, 1930. Spencer Miller made an impassioned request for labor's support for this project and the NJSFL-AFL quickly endorsed the Institute. ${ }^{10}$

Armed with this key labor endorsement, the Executive Committee of the Rutgers Board of Trustees voted to authorize a Labor Institute on September 19, 1930. ${ }^{11}$ Planning for the first Labor Institute, scheduled for summer 1931, began in earnest. Norman Miller, Spencer Miller, and Dr. Eugene Agger (Department of Economics, Rutgers) and Hugh Reilly (NJSF-AFL) met in Carpenters Hall, Newark, NJ, on December 1, 1930 to formulate themes and an agenda. However, differences surfaced regarding what direction the Institute might take. Norman Miller wrote: 
I extracted from Spencer Miller and Hugh Reilly a promise that the Institute would be entirely devoted to educational topics and that under no circumstances would partisan politics be permitted. .. . Another problem was the difficulty we at Rutgers would face if industry were not fully informed as to the nature of this project. The labor men agreed with me and we adopted a plan whereby I would be authorized to invite not less than twenty officials of industry to attend the Institute as auditors ... we happily found that all labor groups were joined by the State Chamber Commerce and the New Jersey Manufacturers Association for the formation of the Institute. ${ }^{12}$

Inaugurated on June 8-12, 1931, the first Rutgers Labor Institute attracted 149 delegates. Philip Brett attended as the Acting President of Rutgers. Arthur Quinn and Hugh Reilly, respectively president and secretary of the NJSF-AFL, also were in attendance. The theme for the Institute was "Unemployment." The liveliest discussion was engendered by Professor J. Douglass Brown of Princeton University who advocated unemployment insurance as part of an eight-point economic recovery program. ${ }^{13}$ The Rutgers Labor Institute continued to offer labor education throughout the Depression and New Deal era of the 1930s, and hosted the week-long Summer Labor Institute annually.

\section{WWII and the Establishment of IMLR}

There is general agreement among the remaining original members of the IMLR that its establishment arose directly out of the World War II experience. Beginning around 1944 and 1945 Rutgers University administrators and officials from state AFL and CIO federations held preliminary discussions concerning the expansion of university services for labor education throughout the state. This contemplated expansion was linked to the larger responsibilities assumed by universities and extension programs in conjunction with federal defense mobilization and production programs. ${ }^{14}$

Prior to direct American involvement in the war, the Roosevelt administration laid the groundwork for education programs relating to vital defense industries. On October 25, 1940, the Engineering Defense Training program was authorized under the Civil Functions Appropriations Act. This act allotted $\$ 9$ million dollars to assist universities (having an established four-year engineering curriculum) in giving short-term engineering courses and additional training for industrial workers engaged in defenserelated production. By February 1941, the Rutgers plan for Emergency Defense Training (EDT) was submitted and approved by the U.S. Commission of Education. Dean Parker H. Daggett was appointed director of the Rutgers University EDT, which combined the University Extension and Engineering Departments. ${ }^{15}$ 
The implications of the looming war was the predominant theme of the Labor Institute held between June 9-12, 1941, under the title of "Labor \& National Defense." Among the major topics of discussion were: the importance of defense training, civil defense, the role of women and the function of the labor press in the war effort.

American universities were further integrated in to the war effort with the enactment of the Labor-Federal Security Appropriations Act in July of 1941. This act authorized chemistry, physics and managerial courses, along with engineering classes to form an integrated Engineering, Science and Management Defense Training program (ESMDT). The first ESMDT class at Rutgers was offered in September. Following Pearl Harbor, the program became ESMWT (war training). By May 2, 1942, 10,165 people had been trained by the Rutgers ESMWT program, either at classes in New Brunswick or in-plant instruction. Total enrollment figures for 763 Rutgers ESMWT classes reached 19,116 by June 1943. Moreover, over 2,380 women (comprising 18\% of the total ESMWT enrollment) had been trained. Rutgers ranked fifth out of 214 universities participating in the program. ${ }^{16}$

Programs such as the ESMWT brought workers to the Rutgers campus in unprecedented numbers during the war years. The spirit of patriotism, sacrifice, and co-operation that imbued both labor and management in service to the war effort was clearly evident in the early Labor Institutes and defense training programs. However, the question remained whether such a labor-management rapprochement would survive the war, or fall prey to such postwar problems of economic recession, unemployment, and reconversion, and strikes.

This concern was addressed at the Rutgers Summer Labor Institute held on June 7-9, 1943, and titled "Labor in the War and After." Because the New Brunswick campus had been given over to the Army for the war effort, the Institute had been moved to the Essex House in Newark. Three hundred delegates heard author Pearl Buck, Vice President Henry Wallace and War Labor Board Chairman (and future U.S. Senator from Oregon) Wayne Morse. The theme of postwar labor relations carried over into the next year when the Institute convened (June 7-9,1944) just after D-Day. Under the banner of "Labor Looks Ahead," the featured participants and speakers included labor chief George Meany and future U.S. Senator, Stuart Symington. ${ }^{17}$

During the same weekend a conference was held at the Monclair Country Club on June 7 th between leading New Jersey industrialists and executive board members of the State Federation of Labor to discuss social legislation. A follow-up meeting occurred on September 15, 1944. These meetings were cited by the local labor press as evidence of growing cooperation between labor and management from which the future IMLR would emerge. ${ }^{18}$ 
On March 14, 1945, Dean Miller sent to President Clothier a report written by J.H. Vertrees of the Extension School entitled, "Report on the New York State School of Industrial and Labor Relations and other University Programs," which delineated the activities of the Industrial Relations School established at Cornell. Vertrees would figure prominently in the evolution of labor education at Rutgers. In its March issue, The New Jersey Labor Herald reported that the Illinois Federation of Labor advocated the creation of a Department of Labor at the University of Illinois. Clearly, New Jersey labor leaders and personnel associated with the Rutgers labor education extension program envisioned the formation of a Rutgers industrial and labor relations school patterned after the Cornell model. Lew Hermann, editor of the Labor Herald, wrote: “ . . . it would be perfectly proper for the New Jersey Legislature to provide a special fund similar to that in New York for the express purpose of establishing an industrial and labor relations school at Rutgers University." 19

With the war's conclusion the Rutgers ESMWT program disbanded. But the spirit of labor-industrial co-operation it fostered helped pave the way for New Jersey's version of the Cornell school. In October 1945, the Labor Herald reported on a proposed November meeting in Newark between state AFL and CIO representatives for the purpose of establishing a state sponsored labor relations school. At the second meeting of the joint AFL and CIO committee held on January 15, 1946, labor representatives approved a tentative draft of a bill to be presented to the New Jersey legislature. This bill was put before the NJ Assembly in February. ${ }^{20}$

On March 15, 1946, the officers of the New Jersey Chamber of Commerce, the New Jersey Manufacturers' Association (NJMA) and representatives of Rutgers met to discuss Assembly Bill No. 254. They expressed two objections to the proposed bill: that the classes for labor and industry would be held separately, and the composition of the Advisory Council for the Institute. This group recommended that Assemblyman Leonard not introduce his bill in the current session so that the Chamber of Commerce and NJMA could appoint a committee to do further research on the subject. The bill eventually died in committee.

Despite the setback, Rutgers signalled its desire to see the proposed Institute realized. In April 1946, University President Robert Clothier spoke at the 25th Anniversary Conference of the WEB. His speech, entitled "A Pattern for Industrial Peace for America," called on the university, labor and management to sit down and work out the details for a joint conference on future education programs in industrial relations. ${ }^{21}$

October 1946, the educational committee of the NJ Chamber of Commerce still expressed critical reservations on certain aspects of Assembly Bill No. 254. The Chamber felt that the university did not need special legislation to establish a labor-management institute and that 
non-governmental sources of funding might be secured by the university. According to longtime IMLR faculty and staff member, Dr. Harold Stark, Joe Vertrees was instrumental in convincing members of the Chamber to support the proposed institute. Vertrees gained the trust of both capital and labor and was a skillful mediator in his own right. At this juncture, supporters for the Rutgers labor institute received an additional boost with the election of Lewis Hermann (Republican) to the state assembly in November 1946. Hermann immediately introduced Assembly Bill No. 250 on February 10, 1947. Shortly thereafter, the Assembly Education Committee met to discuss the measure. On March 18, the bill (A-250) was reported out of committee as "Committee Substitute for Assembly Bill No. 250." It was passed by the Assembly on March 23, 1947.

The Opening of the Institute

Though a legislative entity, the Institute did not become fully operational until July 1947. In the interim the name of the Institute was formally changed from Rutgers Labor Institute to the Rutgers Labor-Management Institute. In September President Clothier officially appointed Dean Miller to head the Institute and chose the members of the first Advisory Council of the IMLR. The original council members (six year appointees), representing labor, management and the public were: Lewis Hermann (New Jersey Labor Herald); Dr. Glenn Gardiner (President of the NJ State Chamber of Commerce); and Nathan Woods (Newark Attorney). Four-year appointees included: Dr. Lillian Gilbreth (a Monclair Industrial Psychologist and Engineering Consultant); Sol Stein (Regional Director, Textile Workers of America-CIO); and John C. Williams (President, Bamberger \& Co., Newark). Among the two-year appointees were: Henry W. Johnson (president, New Jersey Manufacturer's Association; Dr. William L. Tucker, pastor of the Second Presbyterian Church of Princeton; and Michael Woyowicz (Independent Petroleum Workers of New Jersey). ${ }^{22}$

The first staff appointments were also announced. Dr. Richard Wood was appointed as Associate Professor of Management and Labor relations with primary responsibility for directing research activities. Irvine Kerrison received the same academic rank but directed the IMLR's labor program. The first IMLR classes were announced for the Rutgers' Newark branch on September 29, 1947. A sample of class offerings included the following: "Current Trends in Labor Relations;" "Production Supervision-Human Problems;" "Developing Channels of Information Between Management and Workers;" "Labor Negotiations;" "Personnel Management;" "Wage and Salary Administration;" and, "Production Planning and Control." On November 24, 1947, the first class conducted under IMLR auspices, "Effective Speech and Parliamentary Procedure" convened at Van Nest Hall. Three weeks later, the first IMLR management course was offered in 
Newark for foremen, job superintendents, and apprentices of the Damon G. Douglas Company. The Research Program of the IMLR issued its first publication in October 1948, a case study entitled "Joint Safety Program of the Forstmann Woolen Company and Local 656, Textile Workers of America, CIO." Another IMLR first was the establishment of an AudioVisual Service for union and management groups. ${ }^{23}$

Due to health problems, Dean Miller relinquished the post of Director of the IMLR in 1949. He was succeeded by Dr. Richard Wood who assumed responsibility for finding a permanent residence for the IMLR. Initially, the Institute was housed in the Alumni House, Queens College Campus. In December 1949, General Robert Wood Johnson donated 25 acres to Rutgers expressly for the site of a future IMLR building. ${ }^{24}$ The land faced the Raritan River and was bounded by River Road and Cedar Lane on the Highland Park-Piscataway border. Fundraising for a proposed Labor Education Center (LEC) began in August 1954 under the leadership of Lewis Hermann and several prominent New Jersey labor leaders. By then, the site proposed for the LEC shifted to the corner of College Avenue and Hamilton Street. Despite early enthusiasm for the construction of the center, little headway was made. Initial co-operation between labor and management gave way to mutual distrust and suspicion owing to a wave of post-war strikes, passage of the Taft-Hartley Act, and the general antiunion environment which pervaded the country. Though New Jersey industrialists and business leaders publicly expressed support for the LEC, the labor community carried much of the financial burden for the construction of the LEC.

In April of 1957, fundraising efforts received a real boost when the William Green Memorial Fund granted the Institute the sum of $\$ 50,000$ to construct a small auditorium for the proposed LEC. By June 30, 1958, organized labor had contributed over $\$ 200,000$ toward the projected goal of $\$ 300,000$ needed to cover the construction costs of the labor unit of the IMLR complex..$^{25}$ Controversy again arose in March 1959 when the site for the LEC was once again shifted, this time from central College Avenue to the Agricultural College (present site of Cook College). In various fundraising appeals, Hermann had emphasized the central campus location of the College Avenue site. In a letter to Rutgers President Mason Gross he expressed his deep concern that the LEC was now going to be built "out in the woods." Despite Hermann's objections, the site of the center remained at the "Ag School." 26

On June 20,1959, a grand ceremony for the LEC took place in a parking lot next to the site of the present day Cook Administration building, a halfmile from where the Center actually was built, on Ryders Lane. The cornerstone for the LEC was laid on October 28, 1961 at the Ryders Avenue site, nearly sixteen months after the grand ceremony. It was almost another 
year until President Gross hosted more than 2,000 luncheon guests at the formal dedication of the IMLR Center on a cool autumn afternoon of October 20,1962. ${ }^{27}$

The original plans for the IMLR Center called for the construction of three connected wings: one dedicated to labor, one dedicated to the public, and one for management training. Labor had done its part; it now fell to industrialists to make good on its wing. On July 11, 1963, a blue-ribbon group of New Jersey business and corporate leaders met with IMLR administrators in Patterson to discuss plans to raise $\$ 600,000$ for the construction of the Institute's Management Education Center (MEC). The proposed building was to be named in memory of Glen Gardiner, a leading New Jersey industrialist and proponent of conciliatory labor-management relations. Gardiner had played a leading role in marshalling enough support within a skeptical business community to secure passage of the IMLR bill in 1947. Despite energetic efforts by the Gardiner group (including his son) to solicit funds, contributions toward the project dwindled. In an effort to revive the sagging fund drive, Rutgers President Mason Gross intervened directly by authorizing the publication and distribution of a university brochure to 1,500 New Jersey industrialists. Entitled "A Manifesto," the brochure acquainted the business community with the need for a new building to house the management wing of the IMLR. Nevertheless, the business wing of the IMLR failed to materialize. The labor wing stood alone on the Ryders Lane-Clifton Avenue site for another 18 years. ${ }^{28}$

On January 9, 1965, Rutgers officially named the IMLR for the ailing Lewis Hermann, who had played a pivotal role in the creation of the IMLR and had contributed much to the betterment of New Jersey workers and the labor movement. He died a short time later on February 1, 1965. ${ }^{29}$

Despite the accomplishments of Hermann, the New Jersey labor community, and the IMLR administrators and faculty in making the IMLR a reality, this focus turned attention away from the Rutgers Summer Institute which suffered as a consequence. The Summer Institute, which had been held continuously from 1931 to 1957 , ceased operations for a five year period. Revived in the summer of 1963, the event changed from its usual week-long format to a weekend affair. The twenty-eighth Summer Institute, held on the weekend of June 27-29, 1963, featured Dr. Martin Luther King Jr., who was touring the country in support of the famous "March on Washington" that took place in August of that year. This was not the Institute's first involvement with civil rights issues. On July 14-15, 1951, IMLR and the New Jersey State CIO Civil Rights Committee hosted the first Civil Rights and Civil Liberties Conference in New Brunswick. NAACP Executive Secretary Walter White spoke on "Civil Rights and the National Emergency," linking civil rights issues with the Korean War effort. Civil rights conferences sponsored by the IMLR took place periodically throughout the 1950 s. 

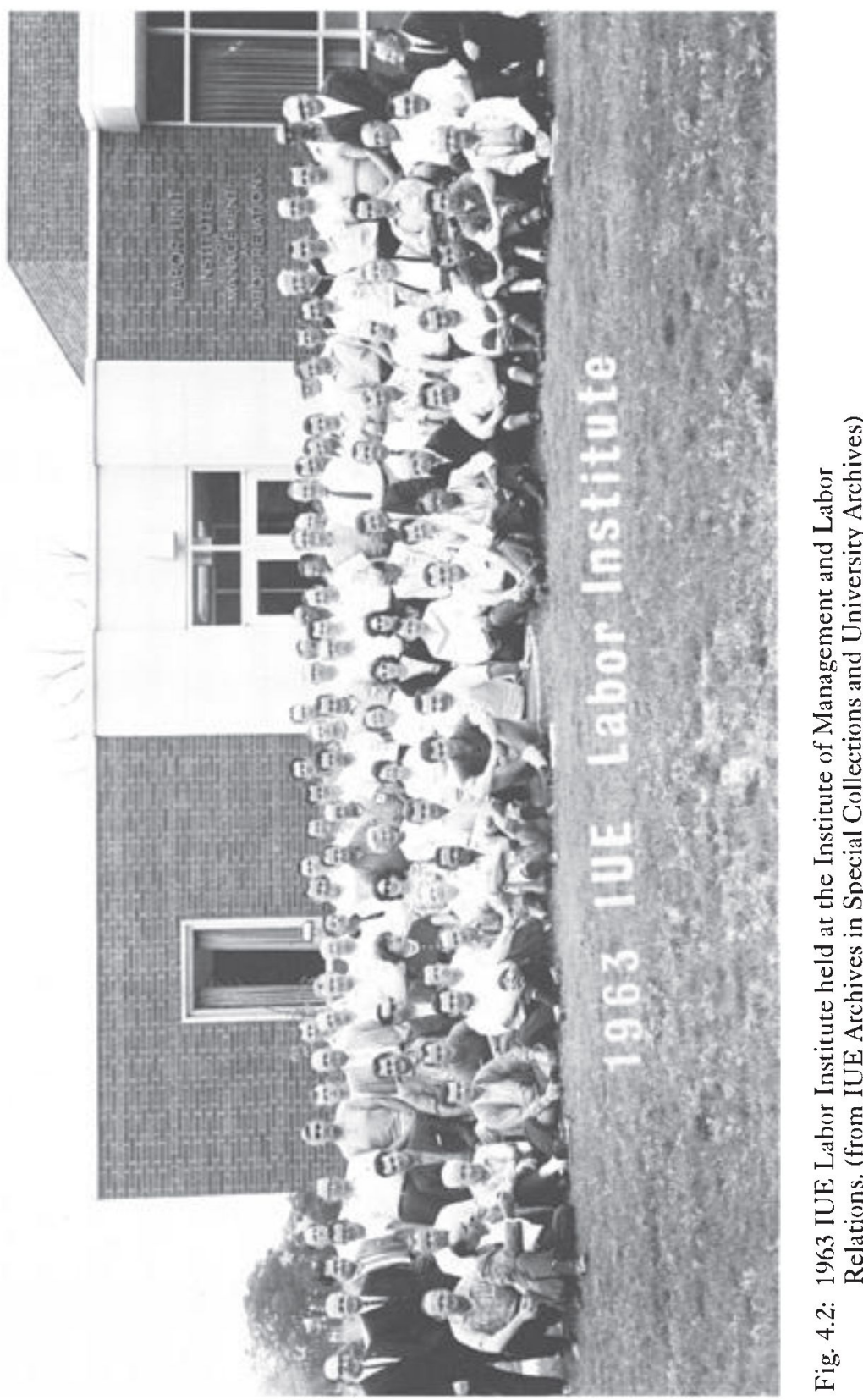
The revival of the Summer Labor Institute was short lived, however, owing to several factors. First, a strike by members of Local 68, Stationary Engineers Union (AFL-CIO) of Newark generated negative publicity for the center. They had been employed as maintenance workers on boilers and air conditioners at Rutgers since 1959, but the university refused the union's request for a signed contract. The sight of striking workers picketing outside the entrance to the Hermann Building ran counter to the ideals of labor-management co-operation espoused by the IMLR. The State AFL-CIO canceled what would have been the twenty-ninth Summer Institute because of the labor dispute. The Summer Institute received a death blow in July of 1965 when the event was abandoned after the New Jersey AFL-CIO cited funding problems. Previously, the IMLR and State AFL-CIO had equally shared funding and sponsorship of the Summer Institute. New Jersey AFL-CIO Secretary-Treasurer Charles Marciante informed the IMLR director that the state federation could not cover its share of the expenses, $\$ 1,800 .^{30}$

Despite the demise of the Rutgers Summer Labor Institute, the IMLR could point to many achievements. Under its successive directors, faculty, librarians, and staff, the Institute (now School) of Management and Labor Relations paved the way for the creation of a bona fide academic program in management and labor relations, and a research library and labor archives to support its activities. A Department of Labor Studies, offering the Bachelor of Arts degree with a major in Labor Studies was established in the evening college at Rutgers starting in September 1967. Initially conceived to offer long-term study for trade unionists, it also replaced the largely defunct certificate program as the capstone of learning opportunities for New Jersey workers. A similar program for a Bachelor of Arts degree in labor studies was established in 1969 at the new Livingston College. Finally, a program of labor studies leading to advanced degrees (Master of Education and Doctor of Education) was approved in the fall of 1968.

The tenth anniversary of the LEC building and the twenty-fifth anniversary of the IMLR were both observed in 1972. Numbers using the LEC had steadily increased from 920 persons in 1962 to 39,000 in 1972. Rutgers President Edward J. Bloustein and New Jersey Governor William Cahill addressed a reception commemorating the event on October 18 at Neilson Dining Hall. ${ }^{31}$ On May 2, 1981, the fiftieth anniversary of labor education at Rutgers was celebrated by a number of events, culminating in the opening of the Sol Stein wing of the LEC and the Raleigh Rojoppi Pavilion. Over 1,000 trade unionists, faculty, government, and community representatives attended the opening, including then Labor Secretary, Ray Marshall. By that date, 1,500 public sector union members and 3,000 private sector unionists had been enrolled in IMLR and Labor Studies programs. Over 2,000 workers were counseled on off-the-job problems through the 
Community Services Counseling Project. From its humble origins the IMLR had become a fully integrated academic institution within the university, without sacrificing its original mission of social uplift and public service.

\section{NOTES}

1. NJ Assembly Bill, 250-A, 1947

2. Dean Albert E. Meder, "The University Providing Service 'To'The People In An Industrial State," 'Text of speech delivered to the National University Extension Association, Thirtythird Annual Meeting, Chicago, Illinois, 2-5 May, 1948: p.5.

3. Alice H. Cook and Agnes M. Douty, Lator Education Outside the Unions (Ithaca, New York: New York State School of Industrial and Labor Relations, Cornell University, 1958).

4. Norman C. Miller, "Events Leading to the Formation of the Annual Labor Institute," Unpublished paper in SMILR Library, February 26, 1960, p. 1. Hereafter cited as "Events."

5. Ibid., p. 3 .

6. Meder, p. 6.

7. Rutgers Targum, 18 November, 1925

8. Richard Dwyer, "An Examination of the Development of Labor Studies at Rutgers University, 1931-1974: A Study in Union-University Cooperation" (Ph.D. diss., Rutgers University, 1975): p. 92.

9. "Events," p. 5.

10. Dwyer, p. 97; Nequ Jersey Federation of Labor 1930 Convention Proceedings, pp. 31-37.

11. Rutgers University Roard of Trustees Minutes, 19 September, 1930.

12. "Events," p.7.

13. Spencer Miller, Jr. and Ruth Taylor, The Pioneer Institute of Labor (Workers Education Bureau of America, 1945), p. 9. Hereafter cited as Pioneer Institute.

14. Oral History Interviews with Professors Harold Stark and Irving Kerrison, June 1994.

15. Ibid.

16. Dates and statistics for the ESMD'Y and ESMIW' were compiled from their Annual Reports for the years, 1940 to 1945.' The reports are located in the Rutgers University Special Collections and Labor Archives, Alexander Library.

17. Pioneer Institute, pp. 35-37.

18. New Jersey Labor Herald, October 1944.

19. A description of Vertrees' role in labor education at Rutgers is contained in a speech prepared by Professor Harold Stark and delivered by Rutgers President Edward J. Bloustein at Neilson Dining Hall, Douglas College at a luncheon marking Vertrees' 100th birthday, October 1, 1987. A text of that speech is deposited at the SMLR Library; New Jersey Labor Herald, April 1945.

20. Meder, p. 12.

21. New Jersey Labor Herald, April 1945; Dwyer, p. 142.

22. Dean Norman C. Miller, "Long Range Planning for Improved Industrial Relations," Unpublished paper, 18 December, 1947, in SNILR Library.

23. Rutgers Nezes Service Press Release, 19 September, 21 November 1947, 2 January 1948; Irving Kerrison, "Education for Understanding," Unpublished paper, n.d., in SNLR Library.

24. Home News, 15 December, 1949.

25. New Jersey Labor Herald, June 1959.

26. Lewis Hermann to Rutgers University President Mason Gross, 12 March, 1959, SMLR Archives.

27. New Jersey Labor Herald, June 1959, November 1961, October 1962; A short film depicting the groundbreaking ceremony was produced by Rutgers University and is stored at the SNILR Library.

28. "Gross Makes Pitch for Helpon New Building at Rutgers," Newark News, 12 June, 1964; Deposited in the SNILR Archives is a brochure entitled, To the Friends of Glen Gardnier, which solicited donations for the proposed building; Rutgers University, A Manifesto from Rutgers-The State University to Leaders of New Jersey Industry, n.d., in SMILR Archives.

29. "Rutgers University Names Building for I.T.U.'s Lewis H. Hermann," Labor News, 14 January, 1965. 
30. "State AFL-CIO Cancels Institute," Willingboro (NJ) Times, 31 July, 1964; "Lacking liunds, AFL-CIO Quits '65 Institute," New Jersey Labor Herald, July 1965.

31. Institute of Management and Labor Relations, 25th Annicersary: 1947-1972, Commemorative brochure in SNILR file. 